\title{
Corruption, Deforestation And Disaster In The Taman Nasional Gunung Leuser Forest
}

\author{
Fernanda Putra Adela, Anwar Saragih
}

Lecturer of Political Science Faculty of Social and Political Sciences, University of North Sumat

\begin{abstract}
This research, describes and analyzes corruption, deforestation and disasters in the area of Gunung Leuser National Park (TNGL). Corruption in the issuance of permits management, illegal logging and forest conversion to plantations. This resulted in the destruction of forests have an impact on the flood disaster in the last 13 years in the area around the Leuser is Langkat, North Sumatra. Formulation of this research is how proper forest management in combating corruption in minimizing disasters caused by deforestation in the Gunung Leuser National Park (TNGL). The theoretical framework of this research using ecological political theory, policy theory and the concept of corruption. This study is a qualitative research paradigm by putting critical case studies to explain the phenomena that occur in analyzing corruption in the sector and the impact caused flash floods and placing primary data and interviews as books and international journals and national journals as secondary data. The results of this study indicate the need for collaborative management in TNGL management in order to eradicate corruption, review of permit management.
\end{abstract}

Keywords: Corruption, Forests and Floods Damage

\section{INTRODUCTION}

Indonesia is a country that has a large forest. Indonesia forest area reached 120 million hectares. Where Indonesia is known as one of the three countries that have the largest tropical forests and biodiversity zones of the richest in the world after Brazil and Zaire country. However, Since the reform era forest destruction due to deforestation worsened. If the calculated communally since 1997 until today, Indonesia Indonesia has lost at least 1.3 million hectares per year ${ }^{1}$.

It took place sporadically and massive. The impact we still feel at the end of 2015 yesterday. Some areas in Indonesia was almost covered by smoke from burning forests. In fact, according to data released by the National Institute of Aeronautics and Space (Lapan) in 2015. The total area burnt 1 July to 20 October 2015 to reach $2,089,911$ hectares. This figure is equivalent to 32 times the size of Jakarta or four times the size of the island of $\mathrm{Bali}^{2}$.

A similar condition also occurs in North Sumatra province, especially Langkat damaged forest in Gunung Leuser National Park (TNGL). Gunung Leuser National Park (TNGL) is a forest conservation area which covers 1,094,692 hectares covering two provinces, North Sumatra and Aceh are rich fauna. There are 8,500 species of plants, 130 mammals and 325 species type of bird or about $1 / 30$ (thirtieth) of the number of birds in the world live in

\footnotetext{
${ }^{1}$ Herman Hidayat, Pengelolaan Hutan Lestari, Partisipasi, Kolaborasi dan Konflik, 2015, Jakarta : Yayasan Obor Indonesia, Page12.

${ }^{2}$ Tiga Bulan, Hutan dan Lahan Terbakar Setara 4 Kali Luas Bali http://www.mongabay.co.id/2015/10/31/tigabulan-hutan-dan-lahan-terbakar-setara-4-kali-luas-bali/ diunduh tanggal 4 november 2017, pukul 12.56 wib.
}

TNGL. Territorial forest in Gunung Leuser National Park (TNGL) in Langkat district, North Sumatra reached 300,000 hectares ${ }^{3}$.

However, now in a critical condition because about $1 / 5$ parts of the forest in the region severely damaged by deforestation since 1978 until now. A total of 42,000 hectares of forest Gunung Leuser National Park (TNGL) langkat damaged by corruption, mismanagement of forests, illegal logging and deforestation over the function lahan.Fenomena TNGL become one of the top portrait of poor forest governance systems throughout the National Park in Indonesia.

From the results of the study of the Corruption Eradication Commission (KPK) in the forestry sector, which has been released some time ago, the potential loss of Indonesia from timber production alone, is estimated to reach $\mathrm{Rp}$. 598-799 triliun over the period 2003-2015. Of which about 700 billion of which came from the destruction of forests in TNGL.

One possible cause is corruption in the forestry sector with the publication of various regulations related to forest and Natural Resources (SDA) concerning regional autonomy, not only is it in Act No. 23 of 2014 does not set the exact boundaries of the resulting potential for overlapping policies, authority granting permission Forest Management Rights (HPH) by the head of the region without going through a clear assessment. Increased revenue (PAD), this Act is potentially a gap of corruption in the licensing terms of the absence of implementing regulations and no clear mechanism for forest management. The licensing process of

${ }^{3}$ Data diperoleh peneliti dari Balai Besra Taman Nasional Gunung Leuser (BBTNGL) 
forest management are critical points of corruption in the process of forest management.

Starting from the preparation of application, research request, boundaries, until the discharge permit management. This permit is then determined from the working area in the field, a comprehensive forest inventory conducted periodically by the license holder, five-year work plan, the forest potential five-year report, annual work plan, to report the results of production. Next is in the timber business, which at this stage is published Letter Legal Forest Products. In the preparation stage application for a license, permit, and reconciliation is very prone to cheating in which the government can take action to benefit certain parties. Potential bribery, extortion and influence sales in each of these points ${ }^{4}$.

Model concessions like this is what happened in the area of Gunung Leuser National Park (TNGL) during this time. Corruption entrance of the licensing process. Despite this fact during the management of the Gunung Leuser National Park (TNGL) is managed by the Center for Gunung Leuser National Park (BBTNGL) which is directly under the Ministry of Forestry.

However, the corruption of forest management on concessions over the land in the region in particular TNGL Besitang subdistrict, Langkat recorded in the last 11 years (2005-2016) has lost 30,000 which is now turned into oil palm plantations. This means that every day is deforested TNGL average 2-3 hectares due to licensing and concessions for forest management. Furthermore, according to the data that can be handled North Sumatra Regional Police (Polda Sumatra) in collaboration with the Aceh Police (Polda Aceh) from September to December, 2015 there were 21 cases and the period January-February 2016 there were 12 cases due to illegal logging and land conversion result forest concessions to oil palm plantations in TNGL 5 .

The problem of deforestation as a result of corruption and granting concessions corporate illegally government of the Right of Forest Management (HPH) in TNGL not only cause losses to the state. However, more than that caused suffering, death to structural poverty as a result of the flood disaster in the last 13 years. At first the

\footnotetext{
${ }^{4}$ Pengelolaan Sektor Kehutanan: "Potensi suap, pemerasan dan penjualan pengaruh ada di tiap titik" http://acch.kpk.go.id/tema/-/blogs/pengelolaan-sektorkehutanan-potensi-suap-pemerasan-dan-penjualanpengaruh-ada-di-tiap-titik-diunduh tanggal 11 november 2017, pukul 15.43 wib.

${ }^{5}$ Data diperoleh peneliti dari Balai Besar Taman Nasional Gunung Leuser (BBTNGL) di Medan 16 Maret 2016 di Medan.
}

first point of the flood in Langkat district just 2 District of the District Bahorok (2003) and the District Besitang (2006). However, the current conditions even worse. According to data from the Regional Disaster Management Agency (BPBD) Langkat in the last 3 years of widespread flooding point into 12 districts. All the 12 districts covering Sub Hinai, District of Tanjung temple, District of Batang attack, District of Padang Tualang, District Secangkang, District Wampu, District Stabat, District Serapit, District Salapian, District Sawit Seberang, District and Sub-district Besitang Gebang6.

Where from 2003 to 2016, almost every year the flood is still flooding residential, agricultural and government offices Langkat regency, North Sumatra. According to data from the Regional Disaster Management Agency Langkat (BPBDs Langkat) losses caused by flooding is very significant to the hundreds of billions of rupiah.

Flood, The first terjadi in November 2003, causing 300 deaths and nearly 400 buildings were destroyed. Second, the flooding that occurred in December 2006 caused an estimated 11,000 hectares of farmland were damaged, 17,000 residents to evacuate and 6 people died. Third, the flood that occurred in October 2013 resulted in about 3,530 houses were inundated by water. Fourth, the floods that occurred in September 2014 led to 5 districts were flooded as high as $100 \mathrm{~cm}$ and 1,976 homes were under water. And fifth, terjadi in January 2015 there was a flood in Langkat as high as $50-70 \mathrm{~cm}$ which resulted5293 houses flooded and one person $\operatorname{died}^{7}$.

The question is how proper forest management in the area of Gunung Leuser National Park (TNGL) in combating corruption? How to minimize the disaster due to deforestation in the Gunung Leuser National Park (TNGL).

\section{METHODS}

This study used qualitative methods. Where researchers collected data by in-depth interviews (indepth interviews) with various speakers who have the capacity and capability related to corruption,

${ }^{6}$ Badan Penanggulangan Bencana Daerah (BPBD) Kabupaten Langkat, Opini Anwar saragih di harian Analisa Medan tanggal 6 September 2015 dengan judul "Kerusakan hutan dan potensi tenggelamnya langkat" http://harian.analisadaily.com/opini/news/kerusakan-

hutan-dan-potensi-tenggelamnya-

langkat/171452/2015/09/17

${ }^{7}$ Opini Anwar Saragih di Harian Analisa Medan tanggal $22 \quad$ April 2014.

http://harian.analisadaily.com/opini/news/kerusakan-

hutan-dan-potensi-tenggelamnya-

langkat/171452/2015/09/17 
destruction of forests, natural resources and disasters. In determining sources Researcher using purposive sampling technique. Where investigators interviewed Academician Prof. University of North Sumatra Hamdani Harahap, Environmentalists are also Lecturer of Philosophy, University of Indonesia (UI), Dr. Saras Dewi, Director of the Environmental Forum of North Sumatra (WALHI North Sumatra) Kusnadi, Head of Disaster Management North Sumatera (BPBDs Sumatra) Saleh Idoan Siregar, Coordinator of the Boundary Zone and Restoration Yayasan Leuser Indonesia (YLI) Nijar Tarin and Chief SPTN region Besitang / Investigator in the Great Hall of the Gunung Leuser National Park (BBTNGL) Tuahman Raya Tarigan. Researchers also collected a variety of other forms of qualitative data such as documents that are useful for the development of a deeper understanding of this research.

\section{RESULTS AND ANALYSIS}

A.Corruption Prevention through Collaborative Management Stakeholders

Forestry sector is one of focus eradication program of the Corruption Eradication Commission (KPK) in recent years. Therefore, the value of state losses caused by corruption in the forestry sector are enormous. Forestry corruption which has now entered into the part of the state of crime-related impact on communities, for example environmental damage, climate change until the disaster caused. Since 2010, the Commission evaluates forest management weaknesses which resulted in the decrease in the number of forest areas that were damaged. According to Commission data 2010 forest management consists of systemic weaknesses of the regulatory aspects, institutional aspects, aspects of governance and human resource management aspects. In the regulatory aspects, for example, the performance of establishing forest boundaries Indonesia is still low. Only $11.8 \%$ of the forest area in Indonesia with the status clear and clean. This means that a new area of forest that can be monitored by the government and controlled by the state. The rest could potentially be exploited irresponsibly and causing losses to the state. In fact, according to data from Nature Climate Change states that the rate of deforestation in Indonesia is the highest in the world. The study describes Indonesia lost 840,000 hectares of forest in 2012, which is greater than the Brazilian who only 460,000 hectares $^{8}$.

\footnotetext{
${ }^{8}$ Selaraskan Langkah Selamatkan Hutan http://acch.kpk.go.id/headline-korupsi-di-sektor-sda diunduh tanggal 13 oktober 2017, pulu 12.00 wib.
}

Forest management Gunung Leuser National Park (TNGL) Based on the Decree of the Minister of Forestry 276 / Kpts-VI / 1997 dated May 23, 1997 concerning the appointment of the Gunung Leuser National Park area TNGL increased to 1,094,692 ha. And wide area SPTN VI Besitang breadth $\pm 126,000$ ha are managed entirely by the Forestry Department were conducted by the Center for TNGL technical implementation under the Directorate General of Forest Protection and Nature Conservation (PHKA).

In accordance with the Regulation of the Minister of Forestry Number: P. 56 / Menhut-II / 2006 on national park zoning guidelines, the Gunung Leuser National Park (TNGL) managed by zoning. Zone area in the national park areas are differentiated according to function and ecological, social, economic and cultural. Zoning Among them are the core zone, wilderness zone, a zone of utilization of the traditional zone, and so on.

In the management and the potential threat of experiencing various difficulties. As forest destruction activities / encroachment, the oil company's corporate existence, and the existence of a security conflict IDPs in Aceh who occupy and clear forest for settlement and plantation / farm community. It is very big influence on the management and conservation efforts TNGL as a whole, and in particular territorial area adjacent to the sub-district and sub-district Besitang Bahorok in Langkat the last 10 years experienced difficulties in land conversion for oil palm plantations to 30,000 hectares.

Deforestation in this TNGL, primarily due to the stakeholders runs respectively in terms of management. Where according to Raymond Bryant in his book entitled Third World Political Ecology is responsible for environment in all three countries of the world including Indonesia is a country (the central government and local governments), Social Organization (NGOs), business and society. Similar conditions also occur in TNGL forest area where the damage caused by the interests of the different stakeholders in the management walk on their own.

Stakeholders that focuses on good actors that are direct movement actor for example the central government and the ministry of forestry (director general of the Nature Conservation), the provincial government (Provincial Forestry Agency), local government (district forestry office). Instead the role of indirect actors eg NGO activists (NGOs), both local and international, academia, donors, private sector and local communities themselves to participate in protecting and preserving the national park.

Corruption in forest management in TNGL mainly due to easily permit granted to oil companies 
to be established in TNGL. Without regard to the completeness of the file permissions and substantial provisions resulted in more forest destruction in TNGL which worsened every day 2-3 hectares TNGL suffered damage from land conversion to oil palm plantations.

An understanding of collaborative management stakeholders or actors become stakeholders in TNGL discourse TNGL future existence. The actors stakeholders have a central role in implementing co-management in TNGL. For example, the role of the central government, provincial government, local government funding for the development of the World Bank and the Foundation, whether international or domestic NGOs and the public has not become an issue of regional government (local government).

Then in collaboration management in anticipation of expected corruption stakeholders actors presenting ideas, solutions and recommendations on the strategic role of TNL that serves as a protection, preservation, utilization and anticipate the actions of illegal logging and corruption. This is done so that the corrupt behavior of the stakeholders themselves can be resolved, especially in plantation land permit issuance or the Forest Tenure (HPH)

This was confirmed by Nijar Tarigan that says
"Manage together stakeholder management is a necessity. This is because stem from budget constraints and costs (budgeting), human resources and a lack of oversight in the management of national parks. On the other hand during the central government has a great self-interest and not distribute the division of authority to manage TNGL stakeholders could be detected. Corruption would occur if it is run each, if the collaborative nature we know who is playing. Not only is it among the stakeholders themselves will each oversee one another so as not corrupt ${ }^{\prime \prime}$

In encouraging management joint Stakeholders include the interests of many parties, both in the order of the government, local governments, businesses and society. Collaborative management is not an easy and effective approach to tackle corruption in the forestry sector. However, in

\footnotetext{
${ }^{9}$ Wawancara dengan Nijar Tarigan (Kordinator Tata Batas Kawasan dan Restorasi yayasan Leuser Indonesia) di Medan, 3 September 2015
}

an atmosphere that is hard wherever required quick action and tactical decisions, for example in tackling corruption Natural Resources (SDA), an emergency forest damage which impact on the environmental conditions it immediately. That is the main goal of collaborative forest management TNGL are the prevention of corruption in the forestry sector which has cost the state up where around 700 billion in the period 2003-2015.

\section{B. Reviewing the License Management}

TNGL forest management permit for this is under the Great Hall of the Gunung Leuser National Park (BBTNGL) because the Leuser region which covers 1,094,692 ha located across the provinces of Aceh and North Sumatra. TNGL a world heritage forest recognized as a Unesco World Agency for nature conservation area which has the best biodiversity in Southeast Asia. TNGL the only forest in the world that still keep four of endangered endemic species that orangutans, rhinos, elephants and tigers who all live together in one area.

According to information from Tuahman Raya Tarigan saying;

"Since the 1997 reforms recorded 53 thousand hectares of forest TNGL damaged by illegal logging and encroachment. Illegal logging in here occured in Langkat, North Sumatra and South Aceh and East Aceh. I myself saw during this time due to the many permission from the central government to coordinate with the local government about the company's timber and land conversion to oil palm. Permission is given easy as turning the palm of the hand without regard to the impact of the future" 10

Currently TNGL conversion of forest areas for timber producers and oil palm plantations are still prevalent. Especially in Langkat one solution to overcome this problem is to review management permits companies or individuals linked group forest management. Wherein the first step is collecting data and information of all financial obligations and other obligations of the license holders to establish an implementation team plantations plantation business assessment, assessment to establish the assessment whether it is feasible or not.

${ }^{10}$ Wawancara dengan Kepala SPTN wilayah Besitang/Penyidik di Balai Besar Taman Nasional Gunung leuser di kantor Balai Besar Taman Nasional Gunung Leuser (BBTNGL) tanggal 4 oktober 2017, pukul 10.00 wib. 
According Kusnadi on plantation business permit reconsideration;

"Not only have an impact on the sustainability of the forest in the Leuser, a re-license companies in the Leuser done in order to establish a system of control of corruption in the forestry sector. For example, enhance operational standards of service (SOP) estate license, then publish to the mass media 6 months period to keep the public as well as future functions to supervise the forestry sector. In order for future action in the forestry sector accelerated clearance does not happen again. Here the greatest potential"11

The findings of licensing that do not meet the criteria and illegal in the future as a strengthening of the argument that a moratorium on the termination for a certain period of activity logging and forest conversion in TNGL to distance themselves from the problem in order to obtain exit long term and permanent so that is massive damage does not happen again. For if the evaluation of this permit does not immediately do so could potentially cause damage to Blood Watershed (DAS) in Leuser.

Watershed is a rain water catchment areas that fit into a network of rivers bordered by a ridge that can separate and divide the flow of rainwater into the beginning to each DAS.Hal this is what happens on the river in TNGL. Where the great rivers such as the River Sei Lepan, Wampu River, River Besitang, Sungai Bukit Lawang and Bahorok River in poor condition as a result of forest destruction.

Sei River watershed Lepan example included a very critical classification reached 1180.60 ha, the critical area of 3324.76 ha and critical potential 20702.17 ha. There is also the land that is not including the critical area of 33229.20 ha. Lepan DAS includes a second priority. While the criteria for watershed damage Sei Wampu conditions based on data for 2013, the total area of 3,164,259.96 ha classified as very critical watershed reach 50660.75 ha, the critical area of $302,998.65$ hectares and will be critical reaches $513,090.70$ ha $^{12}$.

Later, the village of Bukit Lawang Tourism Bukit Lawang or region has an area of 785.49 hectares or 3.65 per cent of the Bahorok river basin,

\footnotetext{
${ }^{11}$ Wawancara dengan bapak Koesnadi Direktur Eksekutif Wahana Lingkungan Hidup Sumatera Utara (Walhi Sumut) di kantor Walhi Sumut tanggal 17 oktober 2017, pukul 13.00 wib.

${ }^{12}$ Harian Waspada Medan tanggal 19 Mei 2014
}

which covers 21493 hectares. According to data Langkat District Government, this area is a floodplain because it sits in a valley. The location is also prone to landslides because 68 percent of the watershed Bahorok has a slope of 30 percent to 70 percent (Kompas August 24, 2015). Meanwhile, Besitang also experiencing critical watershed. Where DAS Besitang reach $14.323,71$ ha or 14.51 percent of the total area of 98701,58 ha. The rate of sedimentation and erosion in the watershed Besitang high enough, because it managed to be first ${ }^{13}$.

If a region is already experiencing severe damage to watersheds caused the flooding potential will also increase. Then the evaluation of the licensing of timber and rubber or oil palm companies must be done immediately.

\section{Utilization of Technology}

Illegal logging in TNGL supervision for this is already done optimally with the supervision of the Forest Police, Arrest in place until prosecuting the illegal logging my head. However, this has not been able to reduce drastically the perpetrators of illegal logging because of the limitations of the supervisory personnel and the areas in the Gunung Leuser National Park take more than 1 million hectares. The use of technology is one solution to prevent such actions ${ }^{14}$.

Drone or more would be known as unmanned aircraft generally regarded as military weapons or means of surveillance. Often referred to as unmanned aerial vehicles (Commonly Referred to as an unmanned aerial vehicle) systems, unmanned air (Unmanned Aerial System) or remotely piloted aircraft (Remotely piloted Aircraft), Unmanned aircraft can also provide low-cost solutions and lowimpact for environmental surveillance in maintaining the ecosystem. Drones are used for conservation purposes such as "eco-drones"15.

This is due to the use of drones has the agility and excellent imaging quality and the ability to map the environmental monitoring.Besides the drones can function asmonitoring mechanism a realtime in case of disasters or illegal logging occurs then distribute the latest message and sends the next

\footnotetext{
${ }^{13}$ Badan Penanggulangan Bencana Daerah Langkat (BPBD langkat)

${ }^{14}$ Ismail, S.Hut, Laporan Akhir Program Pride Campaign tahun 2008-2010 Taman Nasional Gunung Leuser Wilayah Besitang, Yayasan Orang Utan Sumatera Lestari-Orang Utan Information Centre (YOSL-OIC) hal 379-381

${ }^{15}$ Koh, L.P. and Wich, S.A., 2012. Dawn of drone ecology: low-cost autonomous aerial vehicles for conservation. Tropical Conservation Science. 5(2), 121-132. Available online: WwW.tropicalconservationscience.org.
} 
event. On the other hand drones capable of flying at a distance can be adjusted by the computer system.

Indonesia is a country that has the best tropical forest in the world after Brazil. If seen from the costs incurred by Brazil that only 10 million dollars, equivalent to $130-140$ billion rupiah very little compared to a loss of State Indonesia due to illegal logging. According to the Study Data Indonesian Corruption Watch (ICW) during the period 2004-2010, state losses due to deforestation in Indonesia reached Rp 169.7 trillion. The value of it is obtained from the calculation of state revenue shortfall of land and building tax sector as well as a number of licensing and royalties. 700 billion was derived from illegal activities logging alone in Gunung Leuser National Park. Losses \$ 700 billion in TNGL it is still an economic loss of forest ecological TNGL. Not to mention the effect it has is the annual floods from 2003 to 2015 in the area of Gunung Leuser National Park ${ }^{16}$.

\section{CONCLUSIONS}

Corruption in the forestry sector in recent years has been very alarming especially Gunung Leuser National Park Forest (TNGL). State losses according to data from the Indonesia Corruption Watch (ICW), which has caused damage to forests in TNGL in the period 2003 to 2015 has reached 700 billion. This is due to deforestation caused by land conversion, encroachment and illegal logging are also the longer-increasingly sporadic. Motif corruption in the sector such as licensing the use of land for land conversion, logging permits and Forest Tenure (HPH) in TNGL.

On the other hand in addition to the ecological impact also resulted in misery, impoverishment and death of the effect. Where in the past 13 years since 2003 to 2016 each year continues in Langkat floods that are now inundating 12 districts in Langkat initially only concentrated in two sub-districts and sub-district Kahorok Besitang.

For that forest management in TNGL in order to eradicate corruption and to overcome the disaster is a model of collaboration and partnerships between stakeholders such as central government, local government, the Community Social Institutions, employers and society. Program collaboration between actors in this TNGL future requires planning, organization, implementation and supervision under the control of the government, ministry of forestry work units (BBTNGL) and provincial government agencies. It is related to the

${ }^{16}$ Fernanda Putra Adela, Model pengelolaan kawasan ekowisata Taman Hutan Raya (Tahura) Bukit Barisandalam perspektif Politik Ekologi, 2016, Medan : USU review of the company permits TNGL forest management, use of technology and REDD +. The role of the central government as a provider (providers) are the most important part in the management of this collaboration. TNGL management partnerships are the efforts we make corruption in the forestry sector can be overcome and Langkat district disaster does not happen again.

\section{RECOMMENDATIONS}

On proper forest management in the area of Gunung Leuser National Park (TNGL) in combating corruption and minimize disaster due to deforestation is

a. The need for a new model in its handling of collaborative among stakeholders (stakeholders) in the forest-based TNGL social, economic, and culture in order to prevent corruption in the forestry sector are becoming increasingly massive and structured.

b. Coordination of authorities such as the Police, the Indonesian National Army (TNI), the Attorney and the Corruption Eradication Commission (KPK) to crack down on corruption in the forestry sector in TNGL either in the form of illegal logging,land conversion and forest encroachment.

c. Forest sustainability problem is also related to ecological conditions. Where it relates to the human side of society TNGL the last few years to feel the impact of flash floods. TNGL settlement of corruption cases in the future will also automatically effect on the prevention of disasters in the region, especially Langkat TNGL.

d. The need for a new legal regulations on forest management in the form of a single management umbrella and do not overlap each other. This is an effort to ensure corruption in the forestry sector in particular TNGL finished immediately.

\section{REFERENCES}

Book:

Bryant, Raymod, 1998, Power, Konowlegge and

Political ecology in third bword: a review

London : Departemen Of Geography, 1998.

Hartanti, Evi, 2005, Tindak Pidana Korupsi, Jakarta : Sinar Grafika.

Hidayat, Herman, 2015, Pengelolaan Hutan Lestari, Partisipasi, Kolaborasi dan Konflik, Jakarta : Yayasan Obor Indonesia. 
Nurdjana, Teguh Prasetyo dan Sukardi, Korupsi dan Ilegal Loging dalam sistem UndangPelajar.

Desentralisasi,2005, yogyakarta : Pustaka

Riant, Nugroho, 2004, Kebijakan Publik: Formulasi, Implementasi dan Evaluasi. Jakarta:PT.

Elex Media Komputindo.

\section{Research:}

Ismail, S.Hut, Laporan Akhir Program Pride Campaign tahun 2008-2010 Taman Nasional

Gunung Leuser Wilayah Besitang, Yayasan Orang Utan Sumatera Lestari-Orang Utan Information Centre (YOSL-OIC) hal 379381

Koh, L.P. and Wich, S.A., 2012. Dawn of drone ecology: low-cost autonomous aerial

vehicles for conservation. Tropical Conservation Science. 5(2), 121-132. Available online: www.tropicalconservationscience.org.

Putra, Fernanda Adela, Model pengelolaan kawasan ekowisata Taman Hutan Raya (Tahura)

Bukit Barisan dalam perspektif Politik Ekologi, 2016, Medan : USU

\section{Internet :}

Tiga Bulan, Hutan dan Lahan Terbakar Setara 4 Kali Luas

Bali

http://www.mongabay.co.id/2015/10/31/tiga-bulanhutan-dan-lahan-terbakar-setara-4-kali-luas-bali/ diunduh tanggal 4 november 2017, pukul 12.56 wib.

Pengelolaan Sektor Kehutanan: "Potensi suap, pemerasan dan penjualan pengaruh ada di tiap titik" http://acch.kpk.go.id/tema/-/blogs/pengelolaansektor-kehutanan-potensi-suap-pemerasan-danpenjualan-pengaruh-ada-di-tiap-titik- diunduh tanggal 11 november 2017, pukul 15.43 wib.

Badan Penanggulangan Bencana Daerah (BPBD) Kabupaten Langkat, Opini Anwar saragih di harian Analisa Medan tanggal 6 September 2015 dengan judul "Kerusakan hutan dan potensi tenggelamnya langkat"

http://harian.analisadaily.com/opini/news/kerusakanhutan-dan-potensi-tenggelamnya-

langkat/171452/2015/09/17

Opini Anwar Saragih di Harian Analisa Medan tanggal $22 \quad$ April 2014. http://harian.analisadaily.com/opini/news/kerusakan- hutan-dan-potensi-tenggelamnyalangkat/171452/2015/09/17

Selaraskan Langkah Selamatkan Hutan http://acch.kpk.go.id/headline-korupsi-di-sektor-sda diunduh tanggal 13 oktober 2017, pulu 12.00 wib. 